\title{
Comparison of Sentiment Analysis against Digital Payment "T-cash and Go-pay" in Social Media Using Orange Data Mining
}

\section{Perbandingan Analisis Sentimen Terhadap Digital Payment " T-cash dan Go-pay" Di Sosial Media Menggunakan Orange Data Mining}

\author{
Novita Anggraini, S.Kom. ${ }^{1}$, Heri Suroyo, M.Kom. ${ }^{2}$ \\ 1,2Informatics Departement, Bina Darma University, Palembang, Idnonesia \\ Email: 1Novitaanggraini.opi@gmail.com, ${ }^{2}$ Herisuroyo@binadarma.ac.id
}

\begin{abstract}
Abstrak
Saat ini pembicaraan publik di sosial media menjadi salah satu hal menarik untuk diteliti. Dari topik pembicaraan itu menghasilkan komentar yang sebagian besar mengandung opini sentimen. Penelitian ini mencoba menganalisis komentar dengan metode analisis vader, yaitu metode analisis lexicon-based berbasis rule-based sentiment analysis. Vader akan menganalisis text berdasarkan lexicon (a library) yang menghasilkan class sentimen berupa positif, negatif, dan neutral dengan tambahan skor total atau compound (combined score). Penelitian ini memanfaatkan Prepocess text yang meliputi transformation, tokenization, normalization, dan filtering yang bertujuan agar text bisa dianalisis oleh Orange Data Mining guna mendapat perbandingan analisis sentimen terhadap T-cash dan Go-pay di sosial media. Dari penelitian yang dilakukan mendapat kesimpulan bahwa T-cash memiliki nilai sentimen positif lebih tinggi dari pada Go-pay dan memiliki sentimen negatif yang lebih rendah dari pada Go-pay. Namun persamaanya T-cash dan Go-pay memiliki kesamaan pola grafik dimana sentimen terbesar adalah neutral, diikuti oleh positif, dan terakhir adalah negative.
\end{abstract}

Keyword : Analisis Sentimen, Vader, Orange Data Mining, T-cash, Go-pay

\section{PENDAHULUAN}

Saat ini pembicaraan publik di sosial media menjadi salah satu hal menarik untuk diteliti. Dari topik pembicaraan itu menghasilkan komentar yang sebagian besar mengandung opini sentimen. Contohnya topik viral yang sering dibicarakan saat ini adalah digital payment yang merupakan hasil analisis kebutuhan prilaku manusia dan menghasilkan inovasi baru berupa sebuah alat pembayaran digital. Saat ini banyak jenis digital payment yang telah di kenal masyarakat dua dari mereka adalah 
T-cash dan Go-pay, keduanya sama - sama digital payment yang memiliki jumlah pengguna yang banyak saat ini. Dari keduanya lalu muncul pertanyaan siapakah yang lebih baik? Pada dasarnya, penelitian ini mencoba menganalisis komentar dengan metode analisis vader, yaitu metode analisis lexicon-based berbasis rule-based sentiment analysis. Vader akan menganalisis text berdasarkan lexicon (a library) yang menghasilkan class sentimen berupa positif, negatif, dan neutral dengan tambahan skor total atau compound (combined score). Dalam melakukan sentiment analist sendiri penelitian ini menggunakan Orange Data Mining. Penelitian ini juga memanfaatkan Prepocess text dalam Orange Data Mining yang meliputi transformation, tokenization, normalization, dan filtering yang bertujuan agar text bisa dianalisis oleh Orange Data Mining guna mendapat perbandingan analisis sentimen terhadap T-cash dan Go-pay di sosial media.

Untuk melakukan analysis sentimen kita perlu data, ada beberapa cara yang bisa dilakukan untuk mendapatkan data contohnya data opini pengguna yang bisa didapatkan dari media sosial, dengan melihat tren sosial media dan melihat ketersediaan data yang lebih dari cukup, dalam penelitian ini menentukan sosial media yang menjadi sumber data adalah Instagram. Komentar - komentar tersebut diambil dan dikumpulkan dengan metode Web Scraping (mengeruk informasi dari web dengan fokus tertentu dalam kasus penelitian ini adalah komentar pengguna) dengan tools Jarvee yang memanfaatkan satu akun pengguna instagram sebagai media sarana pengumpulan data dengan metode web scraping.

Penelitian ini juga memerlukan alih bahasa dari id ke en karena vader merupakan metode analisis sentimen dengan bahasa english. Namun pada penerapannya vader sangat membantu sekali bagi perusahaan - perusahaan besar untuk dapat menganalisis perspektif pelanggan dengan bantuan Orange Data Mining hal ini dikarenakan jika menggunakan pengkategorian manual seperti pada penelitian sebelumnya dinilai kurang efektif. Maka dari itu dalam proses mengumpulkan data dengan teknik Information Scraping pada penelitian ini memanfaatkan MT (machine translating) menggunakan fungtion GoogleTranslate) dari Google drive spreadsheet dengan filtering ejaan terlebih dahulu barulah di translate guna mendapatkan data dengan source bahasa en (english) untuk menunjang proses penelitian berbasis machine learning menggunakan Orange Data Mining. Penelitian ini mencoba melihat perbandingan dari seberapa positif, negatif, dan netral dari hasil analisis sentimen menggunakan Orange Data Mining. Data yang diambil dalam kurun waktu beberapa bulan postingan terakhir akan dianalisis dan direkaptulasi hasilnya lalu barulah hasil rekaptulasi dibandingkan.

\section{METODOLOGI PENELITIAN}

Metode penelitian ini adalah pengabungan metode Lexicon-based Approach, metode berbasis lexicon (a library) merupakan pendekatan tanpa pengawasan, 
tetapi dalam hal ini bisa menggunakan sebuah kamus dengan antonim dan sinonim dari kata-kata dan frase opini mereka dengan orientasi sentimen masingmasing [1] dengan metode Rule-based Sentiment Analysis metode ini secara efektif menggunakan algoritma rule mining untuk menemukan fitur suatu produk dan untuk mengetahui pendapat yang terkait dengan produk tertentu [2]. Untuk melakukan analisis sentimen berbasis rule-based sentiment analysis dapat mengikuti kerangka kerja berikut (Kundi dkk., 2014) di sesuaikan dengan alur kerja penelitian ini:

1. Pengumpulkan data (Scarping web dari Instagram)

2. Preprocessing Module

3. Lexicon Module (Vader Lexicon- rule- based sentiment analysis)

4. Identifikasi Text-Subjektif (identifikasi sumber data dengan vader lexicon atau mengkategorikan class sentimen)

5. Additional Knowledge Module (Mempelajari pengetahuan tambahan terkait penelitian. Dalam hal ini mencoba menambah stopword, dll dengan re-analysis untuk menemukan hasil analisis yang lebih baik).

\subsection{Metode Pengumpulan Data}

Pada kasus penelitian ini mencoba mencari informasi data yang hanya berupa komentar (sebagai fokus) dari sebuah akun instagram selain itu data yang tidak terkait (komentar) tidak akan di scrape (korek/keruk). Metode web scraping dalam penelitian ini menggunakan aplikasi scraping yaitu Jarvee untuk windows yang memerlukan akun pengguna instagram untuk dapat mengambil komentar dari sebuah link posting kemudian diekstrak dalam bentuk file format *.csv. Web scraping dilakukan dengan menempatkan setiap link posting akun objek kedalam fitur scrape comment dengan ini semua komentar (hanya komentar) akan dikeruk informasinya dari link tersebut. Source bahasa dari data penelitian adalah bahasa indonesia akan tetapi penelitian ini memanfaatkan MT (Macbine Translating) menggunakan fungtion GoogleTranslate0 dari Google drive spreadsheet [6] dengan filtering ejaan terlebih dahulu barulah di translate guna mendapatkan data dengan source bahasa en (english) untuk menunjang proses penelitian berbasis macbine learning menggunakan Orange Data Mining. Pengambilan data terkait informasi mengenai komentar dari setiap posting akan diambil dengan teknik web scraping menggunakan tools Jarvee [7]. Dari setiap link, barulah beberapa postingan selama tiga bulan terakhir, yang terdiri dari beberapa file komentar hasil scraping dari link posting setiap bulannya akan digabungkan menggunakan sebuah perintah pada command prompt yang bertujuan menjadikannya sebuah file dengan format. ${ }^{*} \mathrm{csv}$ yang baru. Beberapa file csv hasil ektract komentar dari url target digabungkan berdasarkan bulan setiap objek dengan bantuan command prompt menggunakan perintah dengan contoh kode program copy / $b$ *.csv GopayNovember.csv.Setelah text ditranslate maka file final untuk data inputan adalah format data Google Spreadsheet

154 | Perbandingan Analisis Sentimen Terbadap Digital Payment "T-cash dan Go-pay" Di Sosial Media Menggunakan Orange Data Mining 
apabila diunduh dari Google Drive file unduhan akan secara otomatis menjadi file dengan format .*xlsx.

\subsection{Metode Pengolahan Data}

Sebelum melakukan analisis sentimen, penerapan text mining untuk mengolah text dalam hal ini adalah prepocess text. Text akan dipisahkan menjadi unit yang lebih kecil (token), akan dilakukan filtering, normalization (stemming, lemmatization), membuat $n$-gram dan tag token dengan label part-of-speech.

\subsection{Metode Analisis Data}

Data hasil Preprocess text selanjutnya akan dianalisis dengan metode analisis sentimen berbasis rule-based sentiment analysis yaitu vader. Proses analisis data bertujuan untuk mendapat kategori class sentimen (positif, negatif, neutral). Text hasil Preprocess text akan di nilai berdasarkan lexicon apakah itu positif, negatif atau neutral dan menambahkan skor total (compound). Ketika Vader mulai bekerja, beberapa perintah menggunakan bahasa pemrograman phyton akan dikerjakan yang paling penting adalah ketika vader memanggil data lexicon dari server NLTK untuk menghitung polarity class sentimen. Menurut [9] pada vader, text diberi peringkat pada skala dari "[-4] Sangat Negatif" hingga "[4] Sangat Positif", dengan penyisihan "[0] Netral". Skor sentimen sebuah kalimat dihitung dengan menjumlahkan skor sentimen dari setiap kata yang terdaftar dalam Vader lexicon dalam kalimat. Pembaca yang berhati-hati mungkin akan memperhatikan bahwa ada kontradiksi: kata-kata individu memiliki skor sentimen antara -4 sampai 4, tetapi nilai sentimen akan dikembalikan dengan nilai antara -1 hingga 1 . Score polarity setiap class akan dinormalkan antara -1 (paling negatif) dan 1 (paling positif) dengan penyisihan 0 adalah netral. Hasil score compound mewakili total skor sentimen yaitu dimana nilai -1 adalah yang paling negatif dan 1 paling positif [10, hlm. 3]. Secara matematika normalisasi, menurut [9], adalah sebagai berikut:

\section{Keterangan}

$$
\text { norm }_{\text {score }}=\frac{x}{\sqrt{x^{2+\alpha}}}
$$

$x=$ Jumlah dari sentimen skor unsur kata kalimat

$\alpha=$ Parameter normalisasi yaitu $\alpha=15$

Di sini bahwa ketika $x$ tumbuh lebih besar, ia akan semakin mendekati -1 atau 1 . Untuk kasus yang sama, jika ada banyak kata dalam dokumen yang di terapkan analisis sentimen vader, akan mendapatkan skor mendekati -1 atau 1 . Dengan demikian, analisis sentimen vader bekerja paling baik pada dokumen pendek, seperti tweet, instagram dan kalimat, bukan pada dokumen besar. 
Vol. 1, No. 1, March 2019

p-ISSN: 2656-5935 http://journal-isi.org/index.php/isi e-ISSN: 2656-4882

\section{HASIL DAN DISKUSI}

\subsection{Skenario Penelitian}

Berdasarkan data penelitian dimana data didapat dari dua objek dari instagram maka jalannya penelitian akan menggunakan type skenario penelitian berikut ini:

Tabel 3.1. Skenario Penelitian

\begin{tabular}{ccc}
\hline $\mathrm{X}$ & T-cash & Go-pay \\
\hline Oktober & Hasil 1 & Hasil 1 \\
\hline November & Hasil 2 & Hasil 2 \\
\hline Desember & Hasil 3 & Hasil 3 \\
\hline Rekaptulasi & Hasil Akhir & Hasil Akhir \\
\hline Perbandingan & Analisis Sentimen T-cash & Analisis Sentimen Go-pay \\
\hline
\end{tabular}

Data tiga bulan terakhir akan dianalisis satu persatu berdasarkan objek. Selajutnya hasil akan di rekaptulasi yang dijadikan hasil akhir penelitian. Kemudian, untuk dapat melakukan analisis sentimen menggunakan Orange Data Mining, penelitian ini menggunakan design penelitian seperti dibawah ini:

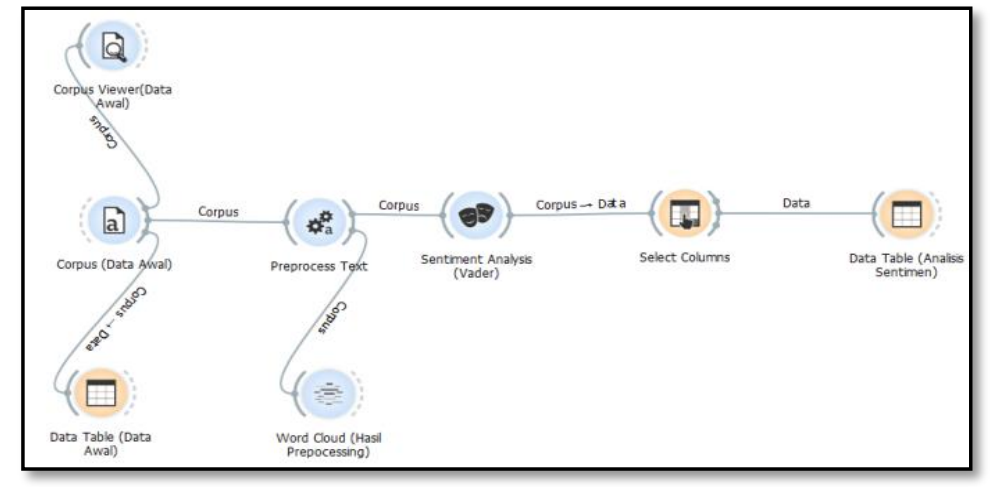

Gambar 3.1. Design Widget Sentiment Analysis

\subsection{Data Inputan (Corpus)}

Dalam penelitian ini yang menjadi data penelitian adalah review atau komentar pengguna dari T-cash dan Go-pay di Instagram. Beberapa hal akan disajikan dalam widget corpus sebagai informasi laporan data yang akan dianalisis adalah: (1) Informasi tentang kumpulan data yang dimuat; (2) Fitur yang akan digunakan dalam analisis teks (dalam hal ini texttrans yang digunakan sebagai fitur yang digunakan untuk analisis); (3) Fitur yang tidak akan digunakan dalam analisis teks dan berfungsi sebagai label atau kelas (seperti username, userURL, dll). Informasi data inputan dari T-cash dan Go-pay bulan Oktober, November, dan Desember dapat dilihat dalam tabel berikut ini:

Tabel 3.2. Rekaptulasi Jumlah Komentar T-cash dan Go-pay

\begin{tabular}{ccccccc}
\hline Objek & \multicolumn{3}{c}{ T-cash } & \multicolumn{3}{c}{ Go-pay } \\
\hline Bulan & Okt & Nov & Des & Okt & Nov & Des \\
\hline Komentar & 8,720 & 5,480 & 8,772 & 8,502 & 7,462 & 7,007 \\
\hline Total & \multicolumn{3}{c}{22,972} & & & 22,971 \\
\hline
\end{tabular}




\subsection{Prepocess Text}

Proses ini dilakukan setelah inputan data, feature analisis adalah field texttrans. Sehingga yang akan melalui proses ini adalah field texttrans.

\section{Transformation}

Langkah pertama dari prepocess text adalah Transformation yaitu mengubah data input. Ini berlaku transformasi huruf kecil secara default.

a. lowercase akan mengubah semua teks menjadi huruf kecil (Where the Voucher $=$ where the voucher)

b. remove accents akan menghapus semua diakritik / aksen dalam teks. naïve $=$ naive

c. Parse html akan mendeteksi tag html dan mem-parsing teks saja. $<a$ href... $>a$ sample of text $\langle/ a\rangle=$ a sample of text

d. Remove url akan menghapus url dari teks. this url http://orange.biolab.si/. = this url.

\section{Tokenization}

Setelah melakukan transformation, langkah kedua dari prepocess text adalah Tokenization yaitu metode memecah teks menjadi komponen yang lebih kecil (kata, kalimat, bigrams).

a. Word \& Punctuation akan membagi teks dengan kata per kata dan membiarkan juga simbol tanda baca. This example. = (This), (example), (.).

\section{Normalization}

Setelah melakukan tokenization, langkah ketiga dari prepocess text adalah normalization yang berlaku stemming dan lemmatization text. Text yang telah dipisahkan kata per kata akan menjadi sebuah text yang beridiri sendiri dalam sebuah kalimat. Komentar biasanya mengandung penulisan yang kurang sempurna (typo). Diharapkan dengan proses normalisasi ini text tersebut akan diketahui maknanya dengan menggunakan:

a. WordNet Lemmatizer menerapkan jaringan sinonim kognitif untuk token (kata) berdasarkan pada basis data lexicon (kamus) bahasa Inggris yang besar dari NLTK (Natural Language Toolkit).

\section{Filtering}

Proses terakhir pada prepocess text adalah Filtering yaitu menghapus atau menyimpan pilihan kata. Disini adalah proses dimana proses filtering kata - kata, simbol yang tidak diperlukan dalam proses selanjutnya (analisis sentimen).

a. Stopwords, menghapus stopwords dari teks (misalnya, menghapus 'and', 'or', 'this' ...). ini dapat dilakukan dengan memilih bahasa yang akan disaring (filter). Pada NLTK server menyediakan stopwords yang dapat diunduh untuk keperluan bahasa. Namun dalam penelitian ini stopwords secara default menggunakan bahasa inggris. Hal ini akan menyaring hanya kata - kata kunci yang disediakan. Berikut ini contoh beberapa stopwords yang akan dihilangkan, stopwords ini terkoneksi dengan data - data pada server NLTK: 
Tabel.3.3. Daftar Stopwords

\begin{tabular}{cc}
\hline English Stopwords & Tambahan \\
\hline I, me, my, myself, we, our, ours, ourselves, you, you're, you've, you'll, you'd, your, yours, yourself, yourselves, he, him, his, & Ya, Min \\
himself, she, she's, her, hers, herself, it, it's, its, itself, they, them, their, theirs, themselves, what, which, who, whom, dll. & \\
\hline
\end{tabular}

b. Regexp menghapus kata-kata yang cocok dengan ekspresi reguler. Default diatur untuk menghapus tanda baca. Berikut ini daftar tanda baca yang akan dihapus dari corpus: $\backslash .||:,|;| !|\backslash ?| \backslash(\mid \backslash)|\backslash||\backslash+|^{\prime}|"|=\left.\left.\right|^{\prime}|-|||\right|^{\prime}\left|\backslash{ }^{\prime}\right| \ldots \mid \backslash$ $|-|-\left.|\backslash \$| \&|\backslash *| \#|@| \%\right|_{-}|>|<|\backslash /| \backslash[\mid \backslash]|1| 2|3| 4|5| 6 \mid$ $7|8| 9|10|$

c. Most Frequent Token, pada dasarnya token merupakan text yang dipisahkan kata demi kata. Dalam fitur ini akan menentukan berapa jumlah token terbanyak yang akan muncul dan akan dianalisis dalam sebuah dokumen (cospus). Dalam penelitian ini menetapkan 1,000,000 sebagai Most Frequent Token.

Setelah melakukan tahapan prepocess text data telah berbentuk text - text terpisah dan dapat dilihat dalam bentuk word cloud pada Orange Data Mining.

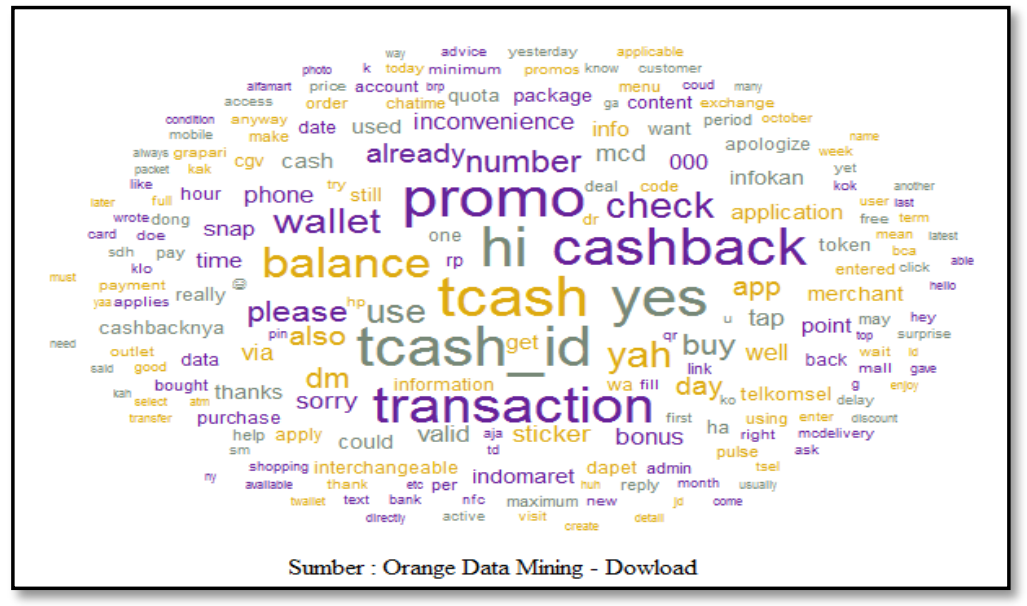

Gambar 3.2. Word Cloud T-cash Oktober

Word cloud dapat digunakan untuk melihat frekuensi kemunculan kata terbanyak. Setelah melalui proses prepocess text, word cloud memberikan tampilan seperti gambar diatas. Dalam hasil tampilan gambar dibawah ini yaitu word cloud (awan kata) dengan frekuensi jumlah kata terbanyak. Semakin banyak frekuensi kemunculan suatu kata, maka semakin besar pula ukuran hurufnya pada word cloud. Word cloud merupakan variasi untuk menampilkan hasil dari tahapan prepocess text. Warna dari kata membuat tampilan lebih menarik dan mudah dipahami, gambar diatas adalah hasil tahapan prepocess text dari data - data yang sebelumnya berisi baris kalimat komentar T-cash selama tiga bulan terakhir. Pada bulan oktober yang menjadi topik pembicaraan pengguna saat berkomentar termasuknya adalah promo, transaction, casbback balance, check. Sedangkan pada bulan 
november pengguna membicarakan beberapa hal seperti balance, promo, transaction, use, point, bonus. Dan pada bulan desember pengguna membicarakan somersault (lelucon game), grandmother (lelucon game), balance, use, pay, cashback, buy. Selanjutnya adalah hasil prepocess text pada Go-pay, pada bulan oktober yang menjadi topik pembicaraan pengguna saat berkomentar termasuknya adalah promo, cashback, pay, check, use, buy. Sedangkan pada bulan november pengguna membicarakan beberapa hal seperti casbback, voucher, ttsgopay (game), scan, money, statisfied, promo. Dan pada bulan desember pengguna membicarakan cashback, alfamart, pay, transaction, email, use, promo, shopping, balance.

\subsection{Analisis Sentimen}

Proses analisis melibatkan algoritma vader untuk mengklasifikasikan polarity (class sentiment) yaitu positif, negatif, dan neutral dengan skor total yaitucompound.

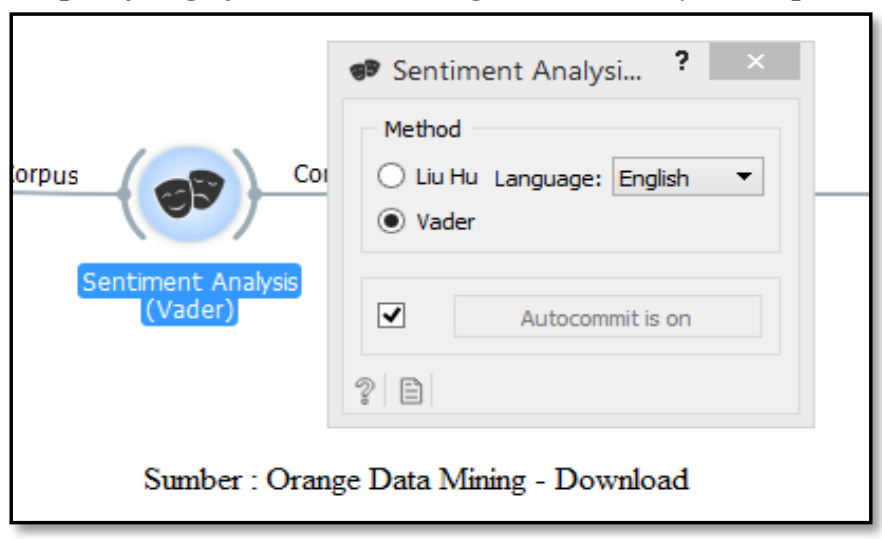

Gambar 3.3. Widget Sentiment Analysis Orange Data Mining

Dari sini data hasil prepocess text akan dianalisis menggunakan metode vader berdasarkan lexicon vader yang terhubung ke data server NTLK. Setelah memilih teknik analisis yaitu vader, vader akan mengkategorikan, serta memberi skor text berdasarkan nilai pada setiap kata - kata yang terdaftar dalam lexicon vader. Hasil akhir dari penilaian adalah skor total yaitu compound. Skor total inilah yang akan direkaptulasi dan dibandingkan hasilnya. Dalam menganalisis ada beberapa atribut variable yang akan difokuskan dimana dari fitur yang menjadi atribut yang digunakan untuk dianalisis (used features) dari widget corpus yaitu kolom Texttrans dan merupakan text hasil translate yang terdapat pada setiap data kementar, yang tujuannya untuk mendapatkan hasil berupa atribut positif negatif, neutral, dan skor total (compound). Dalam penelitian ini akan menentukan mana atribut yang dibutuhkan sebagai hasil dan mana yang tidak, serta atribut meta yang menjadi atribut pelengkap. Berikut ini penjelasan dari pengoperasian widget select column pada orange data mining:

1. Menentukan atribut data (features) dalam file data baru (pos, neg, neu, compound) sebagai fokus utama output analisis. Sehingga dengan penentuan used features 
pada widget corpus yaitu kolom texttrans tujuannya adalah hanya data texttrans yang akan dianalisis menggunakan teknik analisis vader dengan maksud untuk menghasilkan atribut data yaitu pos, neg, neu, dan skor total (compound) pada hasil analisis. Dan variable lainnya adalah sebagai pelengkap.

2. Mengosongkan Variabel target. Jika tidak ada, dataset baru akan tanpa variabel target.

3. Atribut meta dari file data baru (Username, url, dll) berkaitan dengan pengguna yang berkomentar. Atribut-atribut ini termasuk dalam dataset tetapi, untuk sebagian besar metode, tidak dipertimbangkan dalam analisis.

\subsection{Hasil Analisis Sentimen}

Hasil dari analisis sentimen dari penelitian ini adalah seberapa positif, negatif, dan neutral yang dilihat dari skor total (Compound). Maka hasil dapat dilihat dalam tabel data.

\subsubsection{Tabel Data}

Tabel data juga merupakan reaksi hasil untuk menampilkan atribut mana saja yang dipilih untuk ditampilkan sebagai output dalam widget select column pada langkah sebelumnya. Dengan bantuan Google Spreadsheet dari Google Drive hasil analisis pada tabel data hasil analisis sentimen akan dihitung seberapa positif, negatif, dan neutral dengan melihat dari skor total (Compound) dengan formula perhitungan format data numerik [11].

\subsection{Rekaptulasi Hasil Akhir}

Untuk melihat hasil akhir dari hasil analisis dalam bentuk tabel data, penulis melakukan rekaptulasi hasil. Dimana rekaptulasi dilakukan dengan bantuan Google Spreadsheet dari Google Drive. Hal ini untuk mengetahui bagaimana perbandingan analisis sentimen pada digital payement T-cash dan Go-pay berdadasarkan total analisis sentimen komentar pengguna T-cash dan Go-pay selama tiga bulan terakhir pada tahun 2018 berikut simulasi formula menggunakan Google Spreadsheet.

Tabel 3.4. Formula Count dan Countif Pada Google Spreadsheet

\begin{tabular}{ccl}
\hline No & Formula & Keterangan \\
\hline 1 & $=$ countif $(\mathrm{N}: \mathrm{N} ; ">0 ")$ & Untuk menentukan seberapa jumlah Positif dari N (jumlah data) \\
\hline 2 & $=$ countif $(\mathrm{N}: \mathrm{N} ; "<0 ")$ & Untuk menentukan seberapa jumlah Negatif dari N (jumlah data) \\
\hline 3 & $=$ countif $(\mathrm{N}: \mathrm{N} ; "=0 ")$ & Untuk menentukan seberapa jumlah Neutral dari N (jumlah data) \\
\hline 4 & $=$ count $(\mathrm{N}: \mathrm{N})$ & Untuk Melihat jumlah Total Baris Komentar $(\mathrm{N})$ \\
\hline 5 & $=\max 0$ & Untuk mencari nilai terendah dalam entry data \\
\hline 6 & $=\min (0)$ & Untuk mencari nilai tertinggi dalam entry data
\end{tabular}

Setelah mendapatkan frekuensi setiap sentimen (count), kemudian akan dilanjutkan dengan mencari presentase frekuensi sentimen yang akan disajikan dalam bentuk grafik dengan bantuan Google Spreadsheet. Mencari presentase frekuensi sentimen dapat menggunakan rumus [12] berikut ini:

$$
P=\frac{f}{N} \times 100
$$

160 | Perbandingan Analisis Sentimen Terhadap Digital Payment "T-cash dan Go-pay" Di Sosial Media Menggunakan Orange Data Mining 


\section{Journal of Information Systems and Informatics}

Vol. 1, No. 1, March 2019

p-ISSN: 2656-5935

\section{Keterangan}

$\mathrm{P}=$ Presentase

$\mathrm{f}=$ Frekuensi (sentimen)

$\mathrm{N}=$ Total Data

Rekaptulasi dilakukan menggunakan formula Google Spreadsheet dan juga rumus untuk mendapatkan presentase dengan bantuan Google Spreadsheet pada Google Drive [6].

Tabel 3.5. Hasil Rekaptulasi Hasil

\begin{tabular}{|c|c|c|c|c|c|c|c|c|c|}
\hline \multirow{9}{*}{$\begin{array}{c}\text { T- } \\
\text { cash }\end{array}$} & Atribut & \multicolumn{2}{|c|}{ Tcash Oktober } & \multicolumn{2}{|c|}{ Tcash November } & \multicolumn{2}{|c|}{ Tcash Desember } & \multicolumn{2}{|c|}{ Rekaptulasi } \\
\hline & Sentiment & Count & $\%$ & Count & $\%$ & Count & $\%$ & Total & $\%$ \\
\hline & Pos & 3.957 & $45,38 \%$ & 2.147 & $39,18 \%$ & 2.991 & $34,10 \%$ & 9.095 & $39,59 \%$ \\
\hline & Neu & 3.687 & $42,28 \%$ & 2.683 & $48,96 \%$ & 4.435 & $50,56 \%$ & 10.805 & $47,04 \%$ \\
\hline & Neg & 1.076 & $12,34 \%$ & 650 & $11,86 \%$ & 1.346 & $15,34 \%$ & 3.072 & $13,37 \%$ \\
\hline & Total Data & 8.720 & $100,00 \%$ & 5.480 & $100,00 \%$ & 8.772 & $100,00 \%$ & 22.972 & $100 \%$ \\
\hline & Min & \multicolumn{2}{|c|}{$-0,94$} & \multicolumn{2}{|c|}{$-0,91$} & \multicolumn{2}{|c|}{$-0,94$} & \multicolumn{2}{|c|}{$-0,94$} \\
\hline & Max & \multicolumn{2}{|c|}{0,99} & \multicolumn{2}{|c|}{0,99} & \multicolumn{2}{|c|}{0,99} & \multicolumn{2}{|c|}{0,99} \\
\hline & Range & \multicolumn{2}{|c|}{$(-0,94)-(0,99)$} & \multicolumn{2}{|c|}{$(-0,91)-(0,99)$} & \multicolumn{2}{|c|}{$(-0,94)-(0,99)$} & \multicolumn{2}{|c|}{$(-0,94)-(0,99)$} \\
\hline \multirow{9}{*}{$\begin{array}{l}\text { Go- } \\
\text { pay }\end{array}$} & Atribut & \multicolumn{2}{|c|}{ Gopay Oktober } & \multicolumn{2}{|c|}{ Gopay November } & \multicolumn{2}{|c|}{ Gopay Desember } & \multicolumn{2}{|c|}{ Rekaptulasi } \\
\hline & Sentiment & Count & $\begin{array}{c}\text { Present } \\
\text { ase }\end{array}$ & Count & $\begin{array}{c}\text { Present } \\
\text { ase }\end{array}$ & Count & $\begin{array}{l}\text { Present } \\
\text { ase }\end{array}$ & Sum & $\begin{array}{c}\text { Presenta } \\
\text { se }\end{array}$ \\
\hline & Pos & 2.290 & $26,93 \%$ & 3.197 & $42,84 \%$ & 2.310 & $32,97 \%$ & 7.797 & $33,94 \%$ \\
\hline & Neu & 5.118 & $60,20 \%$ & 2.867 & $38,42 \%$ & 2.983 & $42,57 \%$ & 10.968 & $47,75 \%$ \\
\hline & Neg & 1.094 & $12,87 \%$ & 1.398 & $18,73 \%$ & 1.714 & $24,46 \%$ & 4.206 & $18,31 \%$ \\
\hline & Total Data & 8.502 & $100,00 \%$ & 7.462 & $100,00 \%$ & 7.007 & $100,00 \%$ & 22.971 & $100 \%$ \\
\hline & Min & \multicolumn{2}{|c|}{$-0,96$} & \multicolumn{2}{|c|}{$-0,89$} & \multicolumn{2}{|c|}{$-0,95$} & \multicolumn{2}{|c|}{$-0,96$} \\
\hline & $\operatorname{Max}$ & \multicolumn{2}{|c|}{0,98} & \multicolumn{2}{|c|}{0,97} & \multicolumn{2}{|c|}{0,98} & \multicolumn{2}{|c|}{0,98} \\
\hline & Range & \multicolumn{2}{|c|}{$(-0,96)-(0,98)$} & \multicolumn{2}{|c|}{$(-0,89)-(0,97)$} & \multicolumn{2}{|c|}{$(-0,95)-(0,98)$} & \multicolumn{2}{|c|}{$(-0,96)-(0,98)$} \\
\hline
\end{tabular}

Berikut ini adalah grafik presentase rekaptulasi hasil analisis sentimen T-cash dan Go-pay:

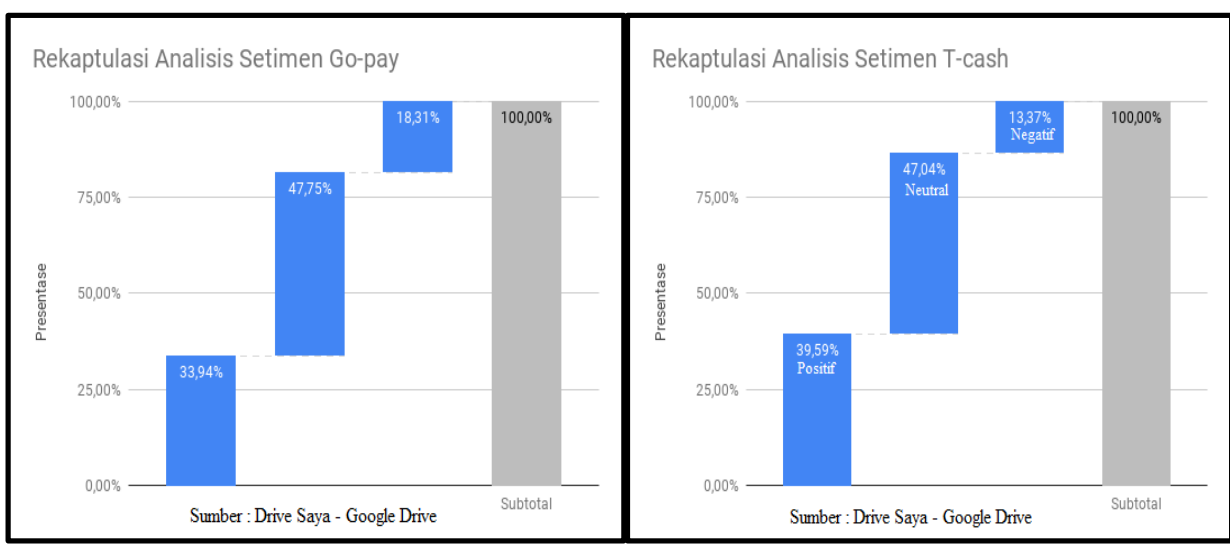

Gambar 3.4. Prentase Analisis Setimen T-cash dan Go-pay bulan Oktober, November, Desember Tahun 2018 
Sehingga dari rekaptulasi hasil, mendapatkan hasil yaitu: T-cash memiliki nilai sentimen positif lebih tinggi dari Go-pay yaitu T-cash sebesar 39,59\% (mendekati 40\%) dan Go-pay hanya sebesar 33,94\% (mendekati 34\%), dan memiliki sentimen negatif yang lebih rendah dari Go-pay yaitu Go-pay sebesar 18,31\% dan T-cash yang hanya sebesar 13,37\%. Namun persamaanya T-cash dan Go-pay memiliki kesamaan pola grafik dimana sentimen terbesar adalah jatuh pada sentimen neutral, diikuti oleh sentimen positif, dan terakhir adalah negatif. Keduanya memiliki banyak sentimen neutral dimana sentimen neutral hampir setengah dari total data (T-cash sebesar 47,04\% dan Go-pay sebesar 47,75\%). Dari hasil rekaptulasi juga penulis mendapatkan range skor sentimen, dimana pada $T$-cash yaitu antara $(-0,94)$ dan $(0,99)$ dan range skor sentimen pada Go-pay yaitu antara $(-0,96)$ dan $(0,98)$.

\section{PENUTUP}

\subsection{Kesimpulan}

Dari hasil analisis sentimen yang dilakukan pada komentar pengguna T-cash dan Go-pay didapat kesimpulan sebagai berikut:

1. Sepuluh besar topik yang menjadi fokus pembicaraan pengguna T-cash adalah mengenai promo, cashback, balance, transaction, use, wallet, point, bonus, pay, check. Sedangkan Go-pay mengenai cashback, promo, transaction, voucher, money, alfamart, pay, scan, use, balance, dimana yang sekiranya menjadi hal penting bagi perusahaan untuk diperhatikan untuk kepuasan pelanggan.

2. Metode analisis vader dapat digunakan sebagai metode analisis sentimen yang menghasilkan tiga class sentimen yaitu positif, negatif, dan neutral dari data awal yang telah melalui proses lemmatization (periksa ejaan atau typo serta prediksi text) kemudian di alih bahasa menjadi bahasa Inggris. Selain itu, jika dibandingkan dengan penelitian sebelumnya [15] analisis sentimen menggunakan metode analisis vader lebih menguntungkan bagi perusahaan untuk penelitian skala besar, dengan berfokus lebih mendalami pada proses lemmatizer sebelum dan sesudah ditranslate, hasil analisis dapat dikatakan sukses.

3. Dengan melakukan analisis sentimen menggunakan metode analisis vader ternyata $T$-cash memiliki nilai sentimen positif lebih tinggi dari Go-pay yaitu $T$ cash dan memiliki sentimen negatif yang lebih rendah dari Go-pay. Namun persamaanya T-cash dan Go-pay memiliki kesamaan pola grafik dimana sentimen terbesar adalah jatuh pada sentimen neutral, diikuti oleh sentimen positif, dan terakhir adalah negatif. Dari hasil rekaptulasi juga penulis mendapatkan range skor sentimen, dimana pada $T$-cash yaitu antara $(-0,94)$ dan $(0,99)$ dan range skor sentimen pada Go-pay yaitu antara $(-0,96)$ dan $(0,98)$.

\section{DAFTAR PUSTAKA}

[1] A. Cambero, "A Comparative Study of Twitter Sentiment Analysis Methods for Live Applications," Theses Rochester Inst. Technol. RIT Sch.

162 | Perbandingan Analisis Sentimen Terhadap Digital Payment "T-cash dan Go-pay" Di Sosial Media Menggunakan Orange Data Mining 
Works, hlm. 43, 2016.

[2] M. Karim dan S. Das, "Sentiment Analysis on Textual Reviews," IOP Conf. Ser. Mater. Sci. Eng., vol. 396, hlm. 012020, Agu 2018.

[3] F. M. Kundi, A. Khan, S. Ahmad, dan M. Z. Asghar, "Lexicon-Based Sentiment Analysis in the Social Web," J. Basic Appl. Sci. Res., hlm. 12, 2014.

[4] "Drive Saya - Google Drive." [Daring]. Tersedia pada: https://drive.google.com/drive/u/0/my-drive. [Diakses: 01-Feb-2019].

[5] "Social Media Automation Software - Social Posting \& Scheduling JARVEE." [Daring]. Tersedia pada: https://jarvee.com/. [Diakses: 01Feb-2019].

[6] C. J. Hutto dan E. Gilbert, "VADER: A Parsimonious Rule-based Model for Sentiment Analysis of Social Media Text," hlm. 10, 2014.

[7] "Sentiment Analysis — Orange3 Text Mining documentation." [Daring]. Tersedia pada: https://orange3text.readthedocs.io/en/latest/widgets/sentimentanalysis.html. [Diakses: 03-Des-2018].

[8] "COUNTIFS - Docs Editors Help." [Daring]. Tersedia pada: https://support.google.com/docs/answer/3256550?hl=en. [Diakses: 09Mar-2019].

[9] E. Kamelta, "PEMANFAATAN INTERNET OLEH MAHASISWA JURUSAN TEKNIK SIPIL FAKULTAS TEKNIK UNIVERSITAS NEGERI PADANG," hlm. 5, 2013.

[10] G. A. Buntoro, "Analisis Sentimen Calon Gubernur DKI Jakarta 2017 Di Twitter," J. Tek. Inform., hlm. 11, 2017. 